EESTI NSV TEADUSTE AKADEEMIA TOIMETISED 1953. II k., nr. I

ИЗВЕСТИЯ АКАДЕМИИ НАУК ЭСТОНСКОИ ССР 1953. Том II, Nㅛ 1

\title{
EESRINDLIKU FILOSOOFILISE JA OHISKONDLIK-POLIITILISE MOTTE ARENEMISEST EESTIS XVIII SAJANDI TEISEL JA XIX SAJANDI ESIMESEL POOLEL
}

\section{E. JANSEN}

Eesti ühiskondliku ja filosoofilise mõtte arenemise küsimusi on Nōukogude Eesti ajaloo- ja filosoofiateaduses seni vähe uuritud. Nii balti-saksa aadli kui ka eesti kodanluse ideoloogid ignoreerisid iseseisva eesti ühiskondlik-filosoofilise mõtte olemasolu või püüdsid sellele anda neile sobiva, reaktsioonilise sisu. Mineviku ühiskondliku mōtte progressiivsed, demokraatlikud elemendid ei olnud ekspluataatorlikele klassidele vastuvõetavad. Kodanlik „metodoloogia" ei vōimaldagi avada ühiskondliku mōtte arenemise objektiivseid seaduspärasusi. Vaadeldes ühiskondliku mõtte nähtusi väljaspool aega ja ruumi, baasilistest nähtustest isoleerituna, muudab kodanlik ,teadus" mineviku kaoseks ja taotleb tegelikult kultuuripärandi hävitamist.

Marksistlik metodoloogia on andnud ka Nõukogude Eesti uurijatele kindla aluse kultuuripärandi probleemide tōeliselt teaduslikuks läbitöötamiseks. Eriti suureks abiks on kultuuripärandi ja ühiskondliku mōtte ajaloo uurimisel J. V. Stalini keeleteadusalased tööd, samuti ka tööd majandusprobleemide kohta. Näidates, et ideed ja teooriad on vastava materiaalse baasi pealisehituseks, rõhutab J. V. Stalin oma teoses „Marksismist keeleteaduses", et ideoloogia on omakorda aktiivne jõud, mis teenindab vastavat baasi.

Oma teoses "Sotsialismi majandusprobleemid NSV Liidus" juhib J. V. Stalin veel kord tähelepanu ideoloogia aktiivsele osale ühiskonna arenemise protsessis, astudes välja majanduslike protsesside stiihilisuse ülehindamise vastu ka ühiskonna sotsialismieelsete formatsioonide tingimustes. Eesrindlikud ühiskondlikud klassid, näitab J. V. Stalin, kasutavad majandusseadusi selleks, et viia tootmissuhted vastavusse tootlike jōudude iseloomuga.' On selge, et eesrindlikku ühiskondlikku klassi teenindab eesrindlik ideoloogia, väljendades funnetatud seadusi. Seejuures tuleb muidugi silmas pidada, et ekspluataatorlik klass, näiteks kodanlus, on võimeline saavutama ainult osaliselt tõepärast tunnetust teda ümbritsevast tegelikkusest. Täieliku peegelduse looduse ja ühiskonnna seaduspärasustest annab aga vaid marksism-leninism.

Seetōttu tuleb iga ideed ja teooriat hinnata ühiskonna arenemise ülesannete seisukohalt antud ajastul.

Et ühiskondlik mōte peegeldab ilmekalt muudatusi baasis, siis on selle

I J. St a li n, Sotsialismi majandusprobleemid NSV Liidus, Tallinn, 1953, lk. 106-107. 
arenemise uurimine paratamatult vajalik ka majanduslike ja sotsiaalsete nähtuste arenemise seaduspärasuste paremaks mõistmiseks.

Eesti ühiskondlik mõte XVIII sajandi lōpust kuni XIX sajandi keskpaigani kajastas kodanlike tootmissuhete rajamist, peegeldades ühiskonna arenemise peamist probleemi - vôitlust feodalismi ja selle igandite vastu. „Ei tohi unustada," kirjutab Lenin, ,et sel ajal, kui kirjutasid XVIII sajandi valgustajad...., kui kirjutasid meie 40. kuni 60. aastate valgustajad, piirdusid kỗik ühiskondlikud küsimused võitlusega pärisorjuse ja selle jäänuste vastu." ${ }_{2}$ Seetõttu tuleb iga ühiskondlikku mōtlejat sel perioodil esiteks hinnata ühiskonna arenemise peaülesande - pärisorjusevastase võitluse - seisukohalt. Nagu näitab Lenini eespooltoodud tsitaat, tähistatakse eesrindlikku mõtet sel perioodil tavaliselt terminiga „valgustuslik mōte". Valgustuslik mõte kahtlemata aitas kaasa kodanlike suhete kujunemisele. Pärisorjuse ja köigi selle sünnituste otsust a v a, täieliku likvideerimise eest võitles aga Venemaa (sealhulgas ka Eesti) revolutsiooniline talurahvas, moodustades ühiskonna rōhuva enamuse. Seetõttu tuleb iga ühiskondlikku mōtlejat sel perioodil teiseks hinnata sellest seisukohast, kuivōrd ta ideoloogia oli demokra at lik, s. t. kuivorrd see väljendas ja teenindas talurahva huve.

Lenin tõstab vene valgustajate tüüpiliste omadustena esile järgmised jooned. Esiteks nad on, hingestatud tulisest vaenust pärisorjuse ja kõigi selle sünnituste vastu majanduslikul, sotsiaalsel ja juriidilisel alal", teiseks on nad ,hariduse, omavalitsuse, vabaduse" tulised kaitsjad. Lõpuks on valgustaja kolmandaks iseloomustavaks jooneks ,rahvamasside, peamiselt talurahva huvide kaitsmine (kes polnud veel täiesti vabastatud või vabanesid alles valgustajate ajajärgul), siiras usk sellesse, et pärisorjuse ja selle jäänuste kaotamine toob endaga kaasa üldise heaolu, ja siiras soov sellele kaasa aidata." 3 Need jooned iseloomustavad ka Baltimaade valgustajaid XVIII sajandi lōpul ja XIX sajandi esimesel poolel.

Hinnates ühiskondliku môtte konkreetset esindajat, tuleb lähtuda antud mōtleja maailmavaatest ja tegevusest kui tervikust, nähes selles esmajoones seda, mis on tüüpiline ja pōhiline ajastu ühiskondlike ülesannete seisukohalt, hoidudes üksikute külgede lahtirebimisest tervikust ning üksikute tsitaatide talmudistlikust ja dogmaatilisest kasutamisest.

Eesti eesrindliku ühiskondlik-poliitilise mōtte arenemises XVIII sajandi teisel ja XIX sajandi esimesel poolel võib eristada kaht pôhimist etappi: 1) balti-saksa kodanluse, kodanlustunud aadli ja sellega seotud intelligentsi hulgast pärinevate valgustajate periood - XVIII sajandi keskpaigast kuni umbes XIX sajandi esimese veerandini; 2) talurahva hulgast põlvnevate valgustajate-demokraatide periood - umbes XIX sajandi esimesest veerandist kuni 1880. aastateni, marksistlike ideede leviku alguseni Eestis. Viimase perioodi vōib omakorda jaotada kaheks alaperioodiks - XIX sajandi esimesest veerandist kuni 1860. aastateni ja 1860. aastatest kuni 1880. aastateni, sest seoses kapitalistlike tootmissuhete kehtestamisega ilmneb ka eesti ühiskondlikus mōttes rida uusi nähtusi.

Baltimaade ajaloo peamiseks iseärasuseks, mis tunduvalt mōjutas ka siinse ühiskondliku môtte arenemist, oli asjaolu, et siin oli feodaalsete kurnajate klass komplekteerunud võõramaistest kolonisaatoritest - saksa röövvallutajatest ja et neile kuulus rida erilisi privileege, mille sarnaseid ei olnud vene aadlil. Seda XVII ja XVIII sajandi jooksul kindlaks kujunenud privileegidesüsteemi nimetatakse tavaliselt ,balti erikorraks". Rahvuslikud vastuolud eesti ja läti talurahva ning balti mõisnike vahel muut-

2. V. I. Lenin, Teosed, 2, kd., 1k. 453.

3. Samas, Ik. 452 
sid klassivastuolud siin eriti teravaks, ja balti erikorra tingimustes võttis pärisorjuslik ekspluateerimine veelgi toorema vormi kui mujal Venemaal.

Esimene valgustajate generatsioon Baltimaadel ilmus XVIII sajandi keskpaiku - siis, kui Baltimaadel nagu kogu Venemaal ilmnes konflikt tootlike jōudude ja tootmissuhete vahel. Esimesed valgustajad kritiseerisid teravalt pärisorjuslikku korda, ei püstitanud aga küsimust kapitalismi arenemise teest. Need valgustajad pōlvnesid balti-saksa aadli enda, peamiselt aga kujuneva balti-saksa kodanluse ja sellega seotud intelligentsi hulgast. See oli loomulik; sest eesti ja läti talurahval puudus haridus, antud ühiskondlike ülesannete alusel oli aga uue ideoloogia sünd paratamatu. Niisuguste valgustajate tegevuse periood kestis Eestis XVIII sajandi keskpaigast kuni XIX sajandi esimese veerandini.

XVIII sajandi keskpaiku hakkasid Eestis nagu kogu Venemaalgi üha kiiremini arenema uue, kapitalistliku süsteemi elemendid. Eestis tekkisid manufaktuurid. Pärisorjuslik möisamajandus seostus üha rohkem nii Venemaa avara siseturuga kui ka välisturuga. Ikka rohkem turustasid balti mőisnikud oma tooteid, eriti teravilja ja viina, otsides üha uusi teid raha hankimiseks. Kuid vanade tootmissuhete alusel jäi mõisnikele toodangu tõstmise peavahendiks ikkagi talurahva pärisorjusliku ekspluateerimise tugevdamine, selle viimine äärmuseni, isegi sel määral, et see tähendas juba tootlike jõudude purustamist. Talumatu ekspluateerimine kutsus esile eesti ja läti talurahva klassivõitluse jätkuva laienemise ja teravnemise.

1760. aastaid tähistas uute tootmissuhete elementide selge ilmnemine. Ka valitsevad klassid ei saanud enam elada täiesti vanaviisi, vaid olid sunnitud vähemalt mõt le m a pärisorjusliku korra „,reguleerimisele”. Neid aastaid, millal Venemaal algas feodalismi ideoloogiliste aluste revideerimine, iseloomustas uute tootmissuhete rajamise ülesandeid teenindava ideoloogia sünd ka Baltimaadel. Uue ideoloogia esindajaks 1760. aastail oli Johann Georg E isen (1717-1779), kes teravalt kritiseeris pärisorjuslikku korda. Eiseni traditsioone jätkas 1780. aastail Heinrich Johann $\mathrm{J}$ a n n a u (1753-1821), näidates pärisorjuse kui ajaloolise institutsiooni kujunemise protsessi. Vastupidiselt balti-saksa mōisnike ideoloogidele väitsid nad, et pärisorjuslik kord ei ole parim kord maailmas ega ole ka igavene, vaid hävib paratamatult.

Mida enam XVIII sajand lõpule lähenes, seda enam näitas kogu Venemaal üha teravnev talurahva klassivõitlus feodalismi lagunemist. Rängalt vapustas pärisorjusliku süsteemi aluseid Pugatšovi poolt juhitud talurahvasõda. Sellest ülestõusust võisid ulatuda otsesed teated eesti talurahvani - oli ju rida Pugatšovi võitluskaaslasi asumisele saadetud Eestisse. Baltimaadel saavutasid talurahva rahutused suurima hoo ja ulatuse 1784. a., millal läti ja eesti talupojad peaaegu kogu Liivimaa kubermangus tōusid üles mõisnike vastu. Reas kohtades tekkis talupoegade veriseid kokkupõrkeid sõjaväega. Talurahva ulatuslikud väljaastumised sundisid tolleaegseid eesrindlikke inimesi paratamatult nägema kehtiva korra ummikut ja ühtlasi talurahva aktiivset osa ühiskondliku arenemise protsessis.

XVIII sajandi lōpul purustas kodanlik revolutsioon Prantsusmaal feodaalsed tootmissuhted ja rajas uued, kodanlikud tootmissuhted. Kodanliku revolutsiooni võit Euroopa ühel suuremal maal soodustas omakorda valgustusliku ideoloogia levimist Venemaal, sealhulgas ka Baltimaadel.

Feodalismivastase vöitluse ülesannete alusel kerkis vene ühiskonnas XVIII sajandi lōpul esile rida väljapaistvaid progressiivse mõtte esindajaid. Suurim neist oli A. N. R a d i št š e v (1749-1802), revolutsionäär, vabariiklane ja demokraat, vene vabastusliku mōtte rajaja.

Baltimaadel peegeldas pärisorjusevastast vōitlust balti-saksa valgusta . jate noorem generatsioon, kellest kōige teravamad ja demokraatlikumad 
olid Garlieb Merkel (1769-1850), Liivimaa pastori poeg, ja Johann Christoph Petri (1762-1851), kodukooliōpetaja Saksamaalt, kes 12 aastat veetis Eestimaa mõisades. Merkeli ja Petri ideoloogias on palju paralleelset. Nad lähtusid mōlemad abstraktse inimōiguse ja russooliku ühiskondliku lepingu teooriast, millel aga feodaalkorra kriitika alusena oli tollal täita positiivne funktsioon. Môlema ülalmainitu vaateis on palju demokratismi jooni ning mõlemate pōhiteosed olid võimsateks süüdistusaktideks balti mõisnike vastu.

Meid huvitab eelkõige Petri, kes oma teostes otseselt lähtus eesti talurahva olukorrast. Petri ei olnud nii hiilgava sōnastusoskusega publitsist kui Merkel, kuid rikkaliku, konkreetse faktilise materjali najal paljastas ta balti parunite kiskjanäo, näidates neid eesti talurahva halastamatute rōhujatena. Petri nägi talurahvas ja aadlis antagonistlikke ühiskondlikke jōude. Oma peateose .Eestimaa ja eestlased" eessōnas ütleb ta otseselt, et ta kavatseb käsitleda talurahvast ja mõisnikke kui ,alatiselt teineteise vastu võitlevaid inimeste klasse." 4 Seejuures suhtus Petri talurahvasse kui aktiivsesse ühiskondlikku jõudu ja nägi talurahvarevolutsiooni võimalikkust. Kujutades Eestimaa mōisnike metsikut vägivallatsemist, rōhutas Petri, et need oudused, mis Prantsusmaal kutsusid esile revolutsiooni, olid väiksemad neist, mida ta nägi iga päev Eestimaal. ${ }^{5}$ Petri varasemates teostes on tunda sümpaatiat Prantsuse revolutsiooni vastu. Kuid kohe ilmnevad ka vastuolud Petri maailmavaates - põhiliselt eelistab ta nagu Merkelgi pärisorjuse likvideerimist „möistlikult”, reformide teel, ja orienteerub absolutismile. Siin avaldub ka selle väljapaistva valgustaja ajalooline piiratus.

Teravalt astus Petri välja balti parunite feodaalse rassismi vastu, kes oma piiramatut võimutsemist eesti ja läti talurahva üle püüdsid õigustada nende rahvaste ,kultuurivõimetusega” ja „loomuliku pahelisusega”. Ainult jōhker pärisorjus on need kord vabad ja suhteliselt kõrgel kultuuritasemel seisnud rahvad surunud looma seisundisse, kirjutab Petri, ${ }^{6}$ ja nad on jälle võimelised jõudma kõrgele kultuurilisele tasemele, kui neile vaid anda vabadust ja haridust.

Petrile on iseloomulik sügav sümpaatia vene rahva vastu. Korduvalt rōhutab ta oma teostes vene rahva andekust ja töökust ning vene sōdurite erakordset vaprust. ${ }^{8}$

Petri nagu Merkelgi ei pöördunud rahva poole, ei toetunud rahvale, ja ta saksakeelsed, välismaal ilmunud tööd ei võinudki jôuda eesti ja läti talurahva hulka. Seega ta ei äratanud ega aktiviseerinud otseselt rahvast. Ta väljendas eeskätt kodanluse ja kodanlustuva aadli huve vōitluses aadlike-pärisorjuslaste vastu. Kuid Merkeli ja Petri teeneks jääb pärisorjuse likvideerimise küsimuse terav püstitamine, mis kajastas ühiskonna arenemise objektiivseid vajadusi antud momendil. Seega peegeldas nende tegevus objektiivselt ka eesti talurahva huve.

XIX sajandi esimene pool oli kogu Venemaa ühiskonnas ajastuks, millal toimus kapitalistlike suhete üha intensiivistuv arenemine, kuni pärast 1861. aastat, nagu näitab Lenin, pärisorjusliku Venemaa asendas juba kapitalistlik Venemaa. ${ }^{9}$ See üleminek teostus keerukate ühiskondlike vastu. olude pōimumise ja talurahva üha teravneva klassivōitluse olukorras. Venemaa rahvaste vabastusliikumine oli aluseks ühiskondliku môtte tormilisele

\footnotetext{
1 J. Chr. Petri, Ehstland und die Ehsten, Erster Theil, Gotha, 1802, Ik. XIII-XIV.

s $\mathrm{S}$ a m a s, 1k. 396.

6 $\mathrm{S}$ a $\mathrm{m}$ a s, 1k. 147, $374 \mathrm{jm}$.

$7 \mathrm{~S}$ a m a s, Ik. $380-381$.

$\mathrm{S}$ a $\mathrm{m}$ a $s, 1 \mathrm{k} .196-198$.

9 Vt. V. I. Len in. Teosed, 17. kd., Ik. 65.
} 
arenemisele. Lenin eristab Venemaa XIX sajandi vabastusliikumises kolm etappi. Ta kirjutab 1914, aastal: „Vabastusliikumine on Venemaal läbi teinud kolm peamist etappi vastavalt vene ühiskonna kolmele peamisele klas. sile, kes vajutasid liikumisele oma pitseri: 1) aadliperiood, ligikaudu 1825. kuni 1861. aastani; 2) raznotšinetsite ehk kodanlik-demokraatlik periood, umbes 1861. kuni 1895. aastani; 3) proletaarne periood, alates 1895. aastast kuni käesoleva ajani." 10 Vastavalt neile etappidele arenes ka progressiivne mōte Venemaal.

Pärast Napoleoni purustamist pääses Euroopas vōimutsema monarhistlik reaktsioon, mille juhtivaks jôuks oli Vene tsaarivalitsus. Märatseva poliitilise reaktsiooni olukorras valitses Venemaal ideoloogias pietism ja müstitsism; halastamatult võideldi valgustusliku mõtte kõigi avalduste vastu. See ei suutnud aga tōkestada pärisorjusevastase liikumise ja ühiskondliku mōtte võimsat tõusu kogu Venemaal. Vene talupojad-sõdurid, samuti eesrindlikud ohvitserid, kes olid 1812. aasta Isamaasōjas võidelnud teiste rahvaste vabastamiseks Napoleoni ikkest, ei tahtnud enam taluda orjust oma kodumaal. 1820. aastatel heiskasid pärisorjuse- ja isevalitsusevastase võitluse lipu Venemaal dekabristid.

Feodalismi kriisi tekkimist Baltimaadel XIX sajandi algul näitas väga selgesti see fakt, et valitsevad klassid ei saanud enam valitseda vanaviisi. Balti parunid panid kõigele uuele vastu tõepoolest meeleheitliku kangekaelsusega. Feodaalid, näitab J. V. Stalin, panid kōikjal vastu uute tootmissuhete rajamisele mitte oma juhmuse pärast, vaid seetōttu, et nad olid eluliselt huvitatud tootmissuhete ja tootlike jōudude vastavuse majandusseaduse teostumise takistamisest. ${ }^{11}$ Kuid talurahva laienev klassivõitlus sundis ka balti paruneid tegema teatud mööndusi uute suhete arenemisele. XIX sajandi esimestel aastatel viidigi Eesti-ja Liivimaal läbi regulative ja talurahvaseadusi. Need seadused, mille ülesandeks oli pärisorjusliku süsteemi pōhimiste aluste kaitsmine, kutsusid aga esile talurahva klassivõitluse üha uusi puhanguid.

Talurahva väljaastumiste, samuti kontinentaalblokaadi olukorras süvenenud majanduslike raskuste mõjul - mis kõik näitasid pärisorjusliku süs teemi ummikut - otsustasid balti mõisnikud lõpuks üle minna pärisorjuse vormilisele kaotamisele. Kogu Venemaal valitseva poliitilise reaktsiooni olukorras kehtestatigi Eestimaal 1816. aastal ja Liivimaal 1819. aastal vastavad talurahvaseadused. Need seadused, sisult küll kodanlikud, teostati pärisorjuslaste poolt: vormiliselt isikliku vabaduse saanud talupoeg, kellelt oli röövitud maa, jäeti mōisniku igakülgse sunnivōimu alla. Talupoeg oli sunnitud temalt riisutud maa tagasi rentima mõisniku poolt dik. teeritud tingimustel teorendi alusel. Nende seaduste tulemusena võis eesti talurahva pärisorjusevastane liikumine vaid laieneda.

- Dekabristid, võideldes ka Baltimaade talurahva vabastamise eest, kritiseerisid teravalt 1816. ja 1819. aasta seaduste silmakirjalikkust. Nende ideoloogia avaldas mõju ka Eestis. Siingi kerkis XIX sajandi algul pärisorjuse süveneva kriisi alusel aadli hulgast esile inimesi, kes ei suutnud leppida pärisorjusliku korra ja isevalitsusega.

Liivimaa aadli hulgast oli pärit Timotheus Eberhard B o c k (1787-1837), kes iseseisvalt arendas välja dekabristidele lähedase ideoloogia. Bock kritiseeris teravalt Aleksander I-st, naerdes välja tema liberaalsed fraasid ja iseloomustades teda kui julma türanni. Lähtudes mitte üksnes Baltimaade, vaid kogu Venemaa olukorrast, nōudis Bock pärisorjuse likvideerimist. „Orjus on niisama mōttetu kui vihatav institutsioon," kirjutas Bock. Pärisorjuse ja senise valitsemissüsteemi kriitika körval andis

10 В. Н. Ленин, Соч, т. 20, стр. 223.

1 Vt. J. Stalin, Sotsialismi majandusprobleemid NSV Liidus, Tallinn, 1953, $1 \mathrm{k} .107$. 
Bock ka uue valitsemiskorralduse kava, mida võib vaadelda kui konstitutsiooniprojekti. Selles nõudis ta tsaarivõimu piiramist rahva poolt valitud esindajatekoguga.

Mitmed dekabristid olid pärit Eestist (Küchelbecker, A. Rosen) või tundsid hästi Eesti olusid ja kajastasid neid otseselt oma töödes (A. Bestužev-Marlinski).

Küchelbecker näiteks kirjutas oma töödes eesti rahva sangarlikust vôitlusest saksa röövrüütlitega XIII sajandil. Rosen nägi eesti talupoegade ränka olukorda, võrreldes eestlaste ja sakslastest mõisnike vahekorda Ameerika pärismaalaste ja veriste hispaania konkistadooride Cortezi ning Pizarro vahekorraga.

Seoses kapitalistlike suhete arenguga ja talurahva aktiivsuse üldise tõusuga ärkas ja kasvas eesti talurahvas sel perioodil üha enam tung hariduse järele. Sellele püüule vastas XIX sajandi esimesel veerandil balti-saksa kirjameeste O. W. Masingi, J. H. Rosenplänteri ja J. W. L. Luce tegevus, kes püüdsid teotseda eesti talurahva haridusliku taseme tõstmiseks ja tema silmaringi avardamiseks. Nende vaadetes on palju piiratust, kuid põhiliselt asusid nad uute suhete arendamise seisukohal ja neis on valgustajalikke jooni. Nende 'veendumuseks oli, nagu väljendab O. W. Masing, ..... et rahva õpetuse eest tõsisemalt hoolt ja muret tuleb kanda, kuida seie ajani sedda veel mitte pole olnud..." ja et „ei ükski assi suremad kahju innimestele ihho ja hinge polest ei joúa tehha, kui aga pimmedus ja rummalus." 12 Rahva hariduslike pün̈ete rahuldamiseks pidasid nad eeskätt vajalikuks eesti keele arendamist, samuti rahvale populaarteaduslike teadmiste andmist. Nende tegevus valmistas objektiivselt ette pinda eesti talurahva enda hulgast pōlvnevate valgustajate tegevusele.

XIX sajandi esimese veerandi lỗpul tõusis esile esimene eesti talurahva hulgast põlvnev kirjanik ja môtleja - Kristian Jaak Peterson (1801-1822). Ta ôppis Tartu ülikoolis. Kui sellal need vähesed, kes eesti talupoegade-pärisorjade hulgast kuidagi olid suutnud välja pääseda ja omandada mingisugusegi hariduse, muutusid sakslasteks (sest eestlane oli talupoja sünonüüm, sakslane tähendas ühtlasi kõrgemat seisust), siis oli K. J. Peterson esimene, kes omandas küllalt avara hariduse ja julges end avalikult eestlaseks tunnistada. Oma filosoofilistelt vaadetelt oli Kristian Jaak Peterson dualist, lähenedes materialismile. K. J. Peterson oli vaba feodaalse ideoloogia kammitsaist ja võttis esimesena kindlalt seisukoha eesti talurahva poolel. Ta nimetas end ,maarahva lauljaks" ja pöördus rahva enda, mitte aga valitsevate klasside poole. On vihjeid, mis lubavad oletada, et Kristian Jaak Peterson ootas talurahva ülestôusu. ${ }^{13}$

Kristian Jaak Peterson oli oma aja erandlik nähtus, kuid mitte juhuslik nähtus - oli seaduspärane, et nüüd hakkas ta $1 \mathrm{ur}$ a h va e nda $\mathrm{h} \mathrm{ul}$ g a s t esile tõusma pärisorjusevastase ideoloogia teadlikke kandjaid.

*

XIX sajandi teisel veerandil toimus pärisorjuslike suhete süvenev laostumine ja kapitalismi üha hoogustuv arenemine kogu Venemaal, sealhulgas ka Baltimaadel. 1820. aastatest alates hakati Baltimaade tööstuses kasutusele vōtma aurujōudu; tekkis uusi suuri ettevôtteid ja kasvas tööliste arv. 1840. aastatel algas Eestis tööstuslik pööre. Põllumajanduse arenemist iseloomustas selle kaubalisuse jätkuv kasv, mõisamajanduse üha süvenev seostumine turuga. Mõisnikud olid sunnitud ratsionaliseerima pôllupida-

12 O. W. M a s in g, Marahwa Näddala-Leht, 1822, 1k. 255.

13 Kristian Jaak Peters on, Laulud, Päevaraamat ja kirjad, Tartu, 1922, 1k. 101. 
mist. Sajandi teisel veerandil hakati tarvitusele vōtma uusi kultuuré (kartul, ristikhein), uusi pōllutööriistu, püüti üle minna mitmeväljasüsteemile, arendati karjakasvatust müügiartiklite saamiseks (meriinolambad, nuumhärjad), laiendati veelgi viinaajamist jne.

Kuid valitsevaks jäid sellal veel pär is orjus likud suhted. Teorendisüsteem tõkestas mōisamajanduse tulukuse tōusu ja selle ümberkasvamist kapitalistlikuks. Teorent laostas talumajandust, muutes talurahva olukorra üha viletsamaks. Säilis ,balti erikord”, see tähendab, vanu tootmissuhteid kaitsvad poliitilised institutsioonid. Nikolai I, kes teostas äärmist poliitilist reaktsiooni, pidas purureaktsioonilist balti aadlit üheks oma kõige kindlamaks toeks, kaitstes igati selle keskaegseid privileege.

Balti aadli käsutuses oli võimas ideoloogiline relv - feodaalne luteri kirik, kes samal ajal oli ka ise feodaal, ekspluateerides otseselt talupoegi. Pastorite ülesandeks oli hoida ,armsat maarahvast" võimalikult täielikus vaimses pimeduses, sisendada talle feodaalsele kurnamisele kuuleka allumise moraali. Selle ülesande teenistuses oli ka mõisnike ja pastorite meelevallas olev, äärmiselt vilets, „piiblisalmide orjusele” rajatud eesti rahvakool. Mida enam teravnes talurahva klassivôitlus, mida enam feodaalid tundsid hirmu oma positsioonide pärast, seda meeleheitlikumalt jutlustati eesti rahvale kuulekat alistumist maistele ülemustele ja maiste hädade vaikset talumist lootuses taevasele ōndsusele. Balti aadli ideoloogid eitasid üha kramplikumalt eesti rahva elu- ja kultuurivōimelisust, väites häbematult, et „kultuurrahvail" (sakslastel) on õigus hävitada teisi, mittekultuurseid, ainult „rassilisi” rahvaid (näiteks eestlasi). „Konservatiivid” balti aadli ideoloogide hulgas kaitsesid seejuures mööndusteta vanu tootmissuhteid; „liberaalid” pooldasid küll uute suhete arendamist, kuid võimalikult aeglaselt, vöimalikult palju säilitades vanast ja võimalikult talurahvahulkade kulul.

Ajastu pōhiülesandeks sel perioodil oli ikka veel vōitlus pärisorjuse vastu. Vanade tootmissuhete likvideerimise ülesanne nõudis nüüd üha otsustavamalt lahendamist.

Eriti ilmekalt avaldus uute suhete valmimine eesti ühiskonnas 1840 . aastatel. Seda näitas eesti talurahva äärmiselt terav klassivõitlus, mis oli osa kogu Venemaa talurahva üha ulatuslikumast võitlusest pärisorjuse vastu. Eesti talurahvas vôitles vanade suhete otsustava likvideerimise eest. Ta võitles mõisnike maamonopoli vastu, teorendi ja kõigi pärisorjusliku kurnamise vormide vastu. Taotledes mõisnike kõigi privileegide - ,balti erikorra" - otsustavat likvideerimist, võitles ta seisuslikkuse vastu ja vabaduse eest ning ühtlasi vabanemise eest feodaalse kiriku ideoloogilisest mōjust.

Selle võitluse kajastusena algas 1830 . aastate lõpul ja 1840 . aastatel hoogne tõus ka eesti eesrindliku ühiskondliku mõtte arengus ja uus periood selle ajaloos - eesti talurahva enda hulgast põlvnevate valgustajatedemokraatide tegevus. Need eesti talurahva ideoloogid väljendasid eesti talurahva taotlusi vöitluses pärisorjuslike suhete likvideerimise eest.

Ohiskondliku mōtte tõus Eestis oli seotud pärisorjusevastase liikumise ja pärisorjusevastase ideoloogia tugevnemisega kogu Venemaal 1840. aastatel. Eesrindliku mōtte tõusu Venemaal mõjustasid ka kodanlik-demokraatlikud revolutsioonid, mis 1848, aastal haarasid Euroopa. Eesrindliku ideoloogia tähtsamateks esindajateks Venemaal olid revolutsioonilised demokraadid A. I. Herzen $(1812-1870)$ ja V. G. Belinski (1811-1848). 1840. aastatel levisid Eestis ka utopistliku sotsialismi ideed. Petraševskilaste ringi tegevus ulatus ka Eestisse, Tallinna intelligentsi hulka.

\section{Eesti valgustajate-demokraatide tegevuse hindamisel tuleb arves-}


tada, et nad tulid eesti talurahva hulgast, kes oli igast küljest aheldatud balti parunite majandusliku, poliitilise ja kultuurilise ülevõimuga. Ajal, millal nad kirjutasid, märatses süngeim poliitiline reaktsioon. Tsaarivôimud jälitasid iga progressiivset mõtet, ranged tsensuurimäärused lämmatasid iga vabama väljenduse ja julgema sõna. Baltimaadel oli 1840. aastatel talurahvaküsimuse käsitlemine trükisōnas absoluutselt keelatud. Isegi erakirjades tuli olla ettevaatlik. Seetōttu pidid tolleaegsed progressiivsed ühiskonnategelased otseste ja teravate väljenduste asemel sageli piirduma kaudsete vihjetega.

Eesti väljapaistvad valgustajad XIX sajandi esimesel poolel ja keskpaiku olid Friedrich Robert Faehlmann (1798-1850) ja Friedrich Reinhold Kreutzwald (1803-1882). Nad olid sōbrad ja neid sidus, nagu Kreutzwald ise ütles, armastus oma rahva vastu. ${ }^{14}$

Nende vaadete kujunemise baasiks oli Eesti elu tegelikkus. Nende progressiivse maailmavaate kujunemise ideoloogilist allikat tuleb aga näha eelkõige eesti rahvaluules avalduvas töötava rahva enda maailmavaates, mille sisuks oli vaen rōhujate vastu, võitlustahe, optimism ja usk paremasse tulevikku. Nad tulid eesti rahva.hulgast, tundsid pōhjalikult folkloori ja armastasid seda. Teiseks avaldas neile mõju loodusteadusliku hariduse omandamine Tartu ülikoolis - môlemad õppisid siin arstiteadust. Tartu ülikool kujunes sellal eesrindliku vene teaduse väljapaistvaks tsentrumiks - seda iseloomustavad sellised nimed nagu Pirogov, Struve jt. Sellega seoses sai Tartu ülikoolist oluline tegur ka eesti ja läti rahva kultuurilises arengus. Nii Faehlmanni kui ka Kreutzwaldi otsus asuda tööle oma rahva kasuks kuulub nende ülikooliperioodi.

See, mida me teame Friedrich Robert Faehlmannist, tekitab meis aus. tust tema kui pärisorjuse vastu võitleja, patrioodi, teadlase ning tugeva tahtega isiksuse vastu. Pärast Tartu ülikooli lōpetamist 1827. aastal teotses ta Tartus, olles varsti tunnustatud sealse parima arstina. Arstikutse kõrval tegeles ta eesti keele uurijana, eesti keele lektorina Tartu ülikoolis, kirjanikuna ja folkloristina. Tema initsiatiivil asutati 1838. aastal Opetatud Eesti Selts eesti keele, folkloori, etnograafia ja ajaloo uurimiseks.

Faehlmanni filosoofiliste vaadete kohta on säilinud väga vähe andmeid, kuid selle pōhjal, mis me teame, on selge, et ta lähenes materialismile. Kreutzwald kirjutab Faehlmanni eluloos, et Faehlmann vältis ühelt poolt idealistide õõnsat fraseoloogiat, kuid teiselt poolt samuti ,,vulgaarsete empiirikute kohmakat materialismi".15 Viimasega mõtleb Kreutzwald ilmselt vulgaarmaterialismi. Kaasaegsete hinnangud näitavad, et Faehlmann oli suurte võimetega teadlane, kes pōlgas igasugust dogmatismi ja lömitamist autoriteetide ees, ja kes praktikast oli suuteline tegema väärtuslikke üldistusi.

Faehlmanni sotsiaalseid vaateid iseloomustab vaen feodaalkorra ja kōigi selle sünnituste vastu, viha balti parunite kui eesti rahva orjastajate ja rōhujate vastu, eesti talurahva huvide kaitsmine.

Lähtudes eesti rahva folklooris avalduvast eesti ajaloo kontseptsioonist, näitas Faehlmann enamikus oma teostes ja esinemistes, et saksa rüütlid XIII sajandil olid röövvallutajad, kes ristiusu levitamise ettekäändel orjastasid eestlased ja kiskusid enda kätte neile kuuluva maa. „.... Ja see orjus hakkas kehtima kogu ajaloos küll täiesti ennekuulmatul kujul, sest sakslane ju oma kiidetud pōhjalikkuse juures ei saanud teha midagi poolikult" 16 - nii rääkis Faehlmann oma avaloengul Tartu ülikoolis, kus ta kuulajaiks olid peamiselt parunite pojad.

14 Kreutzwaldi kiri Faehlmannile 24. detsembrist 1842.

$15 \mathrm{~F}, \mathrm{R}$. Kreutzwald, Dr. Friedrich Robert Faehlmanns Leben, Verhandlungen der Gelehrten Estnischen Gesellschaft, kd. II, vihik 4, lk. 21.

16 Loengu kảsikiri ENSV TA Kirjandusmuuseumis. 
Lakkamatult rōhutas Faehlmann oma kirjutustes eesti rahva kõrget kultuurilist taset ja vaba, idüllilist elu ,kuldsel muinasajal”, enne sakslaste vallutust. Niisuguse idealiseerimise eesmärgiks oli sisendada eesti rahvasse usku oma loovatesse võimetesse ja tōestada teistele rahvastele eesti rahva kultuurivöimelisust.

Eesti talurahva Faehlmanni enda väljenduse järgi meeleheitliku ${ }^{17}$ olukorra pōhjusena nägi Faehlmann pärisorjusliku ekspluateerimise vorme valitsevat teorendisüsteemi ja talumaade mōisastamist, viidates sellele otseselt ka oma avalikes kirjutistes. ${ }^{18}$ Faehlmann näitas, et eesti talurahvast ekspluateeritakse halastamatult balti mōisnike poolt, kellel pole mingit öigust sellele maale, mida nad valdavad. ${ }^{19}$

Talurahva klassivōitluse avalduste - väljarändamise ja 1840. aastatel ōigeusku siirdumise - põhjuseks, nagu näitas Faehlmann, oli eesti talurahva halastamatu ekspluateerimine balti-saksa mõisnike poolt. Talupojad, kirjutas Faehlmann, on valmis tegema köik, et pääseda saksa „nülgijate” küüsist. ${ }^{20}$

Faehlmann armastas sügavalt oma rahvast, oma ,nöiduse kütkeis ja saksalaste haardes" vaevlevat kodumaad. Ja ta oli veendunud, et orjastajatel tuleb tulevikus veel vastust anda. ${ }^{21}$

Faehlmann tegutses teadlikult ja aktiivselt eesti rahva äratamiseks, mōistes seejuures folkloori suurt tähtsust võitluses feodaal-klerikaalse ideoloogia vastu. Ta alustas materjalide kogumist eesti rahva eepose „Kalevipoja" koostamiseks. Tema ilukirjanduslikud tööd, samuti populaarteaduslikud kirjutised olid otseseks vastandiks sellal pastorite poolt talurahvale pakutavale usulisele rämpsule, mis moodustas peaaegu kogu selleaegse "rahvakirjanduse". Tarvitseb vaid vaadata selleaegsetes ,rahvaväljaannetes" esinevaid pealkirju, et selles veenduda. Rahvast rõoomustati lugemispaladega, nagu: „Ignatsius ja Polikarpus, Kristuse tunnistajad”, „Mispärast hoian luteruse usu koguduse poole?”, „Luteruse manitsus abielu rahvale" jne., jne. Talurahvale hävitávat mõju avaldavate korduvate viljaikalduste puhul 1840. aastatel õpetasid Faehlmann ja Kreutzwald rahvast, kuidas kasutada nälja ajal leiva jätkuks mitmesuguseid taimi, ja rõhutasid põllumajanduse ratsionaliseerimise ning uute kultuuride, eriti kartuli kasvatamise vajadust. Pastorid aga jutlustasid oma „rahvaväljaannetes", et jumal vôib nälja ajal ka ime läbi toidulisa anda, kui vaid ollakse küllalt jumalakartlik ja hoitakse luteri kiriku poole: mitte kartul ei aita inimest, vaid jumal. ${ }^{22}$

Samal ajal kavandas Faehlmann eesti rahvaeepost ja kirjutas oma käsikirjas:

„Tahan laulda isamaa haavadest,

Tahan laulda eesti rahva kannatustest ja häbist!" 23

Faehlmanni ümber kogunes ka teisi demokraatlikult meelestatud haritlasi. Nende hulka kuulus eeskätt muidugi ta sōber Friedrich Reinhold Kreutzwald, edasi näiteks Johann Jakob Nocks (1800-1890), hiljem kooliõpetaja; Dietrich Heinrich Jürgenson. (1804-1841), Tartu Seminari ins-

17 Faehlmanni käsikiri „Mein Streit mit Nolcken u. Liphart”, ENSV TA Kirjandusmuseumis.

I8 F. R. F a ehIma n n, Tūhhi jut, tühhi lorri, tühhi assi, tūhhi kōik, Tarto- ja Vōrroma Kalender, 1842, Ik. $54-56$ ja 60 .

19 Faehlmanni käsikiri „Mein Streit mit Nolcken u. Liphart".

20 Faehlmanni kiri Kreutzwaldile 27. septembrist 1845. seumis.

21 Faehlmanni käsikirjaline sissejuhatus "Kalevipojale”, ENSV TA Kirjandusmuu-

${ }_{22}$ Leivakorvikene ehk ōppetussed ja juttustamissed marahva kassuks üllespandud, 1847. Ik. $20-22$.

23 Faehlmanni käsikirjaline sissejuhatus „Kalevipojale”.

4 ENSV Tead. Akad. tolmetised 1 
pektor, ja teisi. Kreutzwald kirjutab selle kohta hiljem: „Pikkamisi tekkis väike ring, mis aeg-ajalt kokku tuli ja eesti huvidega tegeles." ${ }^{24}$ Balti parunid seostasid Faehlmanni nime talurahva väljaastumistega 1840. aastal. Faehlmann ei olnud revolutsionäär, kuid tema tegevus sellal aitas kindlasti kaasa eesti talurahva aktiviseerimisele, ta teadlikkuse tōstmisele.

1830. aastate lōpul algas ka eesti suurima valgustaja-demokraadi Friedrich Reinhold Kreutzwaldi tegevus. Kreutzwaldi tegevus haarab väga pikka perioodi - 1830. aastate lōpust kuni 1880. aastateni. Selle vältel, 1850.-1860. aastatel, teostus ka Eesti ühiskonnas nagu kogu Venemaal uute, kapitalistlike tootmissuhete kehtestamine. See üleminek toimus eesti talurahva klassivōitluse teravate puhangute olukorras, eriti 1850. aastate lôpul ja 60. algul. Ka eesti talurahva tolleaegne klassivōitlus oli üheks ülevenemaalise revolutsioonilise situatsiooni väljenduseks.

Uutele suhetele Baltimaadel avardas teed rida 1840, aastate 1ōpust kuni 1860. aastateni teostatud kodanlikke reforme. Algas talude hoogne päriseksostmine ja siirdumine raharendile. Kiiresti arenes suurtööstus ja osana ülevenemaalisest proletariaadist formeerus eesti töölisklass, alustades 1870. aastatel juba vōitlust kapitalistliku kurnamise vastu.

Järjest selgemini hakkasid nüüd ilmnema uued, kapitalistlikule süsteemile omased vastuolud. Süvenes talurahva diferentseerumine, kujunes välja uus kurnajate klass - eesti külakodanlus, kulaklus.

Kuid kapitalismi kiiret arenemist pidurdasid ikka veel feodalismi igandid, „balti erikord" - balti-saksa mōisnike privileegid. Sedavõrd, kuivőrd need säilisid, astus eesti talurahvas veel ühiselt välja pärisorjusliku ïhiskonna klassina.

Koos kapitalistliku tootmissüsteemi võiduga jōudis lōpule ka eestlaste rahvuseks konsolideerumise protsess.

Et Kreutzwaldi maailmavaateline väljakujunemine ja ühiskondliku tegevuse algus langevad 1830.-1840. aastatesse, siis ei saa XIX sajandi esimese poole eesrindlikku ühiskondlikku mōtet Kreutzwaldita kuidagi käsitleda. Kreutzwaldi maailmavaade, looming ja tegevus olid murrangulise ajastu keerukate vastuolude peegelduseks.

Kreutzwald viis lōpule Faehlmanni poolt alustatud ürituse - eesti rahvaeepose „Kalevipoja” koostamise. Kui Kreutzwald poleks andnud midagi mud peale „Kalevipoja”, ka siis tuleks teda hinnata eesti suurima kirjaniku ja valgustajana XIX sajandil. Kuid Kreutzwaldi ühiskondlik tegevus on väga ulatuslik ja mitmepalgeline. Ta on eesti demokraatliku rahvusliku kirjanduse rajaja, eesti folkloristika rajajaid, väljapaistev eesti keele arendaja, publitsist ja paljude populaarteaduslike teoste autor. Kreutzwald on andnud palju väärtuslikku eesti ajaloo, arheoloogia ja etnograafia alal. Ka arstina püüdis Kreutzwald teotseda rahva kasuks, aidates kaasa eesti rahva tervishoiutaseme tõstmisele. Kogu oma mitmekülgses tegevuses tõuseb Kreutzwald esile kui progressiivse ühiskondliku môtte väljapaistev esindaja, kui tōeline valgustaja ja demokraat.

Filosoofiliselt maailmavaatelt lähenes Kreutzwald materialismile. Ta ei ole kirjufanud otseselt filosoofilisi traktaate, kuid tema kirjades avaldatud mōtete, tema arstiteaduslike jt. kirjutiste pōhjal on selge, et ta ei kahelnud meie teadvusest sõltumatu objektiivse reaalsuse olemasolus. Ta rōhutas, et see objektiivne tegelikkus allub kindlatele seaduspärasustele, „sest kindlal looduse seadusel ei ole kuskil vankumist, ega või midagi vastu seadust sündida..." ${ }^{25}$ Oma maailmavaadet nimetas Kreutzwald ise 100 d u s f i l o s o of il is e ks, vastandades seda näiteks pastor J. Hurda t e o -

24 Kreutzwaldi kiri Yrjö Koskinenile 23. angustist (4. septembrist) 1866.

25 F. R. Kreutzwald, Kodutohter, Tartu, 1879 , 1k, 8. 
loogilisele maailmavaatele. ${ }^{26}$ Ohes kirjas on Kreutzwald end otseselt nimetanud materialistiks. ${ }^{27}$

Kreutzwald lähenes stiihiliselt ka tegelikkuse seaduspärasuste dialektilise loomuse möistmisele. Ta nägi loodust ja samuti ühiskonda alatises liikumises ja muutumises. „Looduses ei ole paigalpüsimist ega surma, ka kõdunemine ise on elu muutunud kujul, kuid väga mitmekesistes avaldusvormides," ütles $\operatorname{ta}^{28}$ Seejuures käsitles Kreutzwald liikumist arenemisena madalamalt kōrgemale. Kogu Kreutzwaldi tegevuse aluseks on ta vankumatu usk progressi ja edasiminekusse.

Mõnevōrra lähenes Kreutzwald ka vastandite võitluse kui liikumise sisu mõistmisele. Paljudes Kreutzwaldi kirjutistes esineb môte, et va na paneb u uele meeleheitlikult vastu, et võitluseta pole progressi. Kuid ta ei olnud siin oma seisukohtades järjekindel. Oma vaadetes ei jōudnud Kreutzwald klassivōitluse nägemiseni ühiskonnas. Kuid ilukirjanduslikes teostes, mida ta lõi rahvaluulest lähtudes, asus Kreutzwald klassivõitluse positsioonile.

Kreutzwald ei suutnud siiski seletada liikumist mateeria omadusena ega läbi saada selle ,algpõhjuseta”. Nii ei jōudnud ta ateismini, vaid jäi peatuma deismile. Kuid valgustajate deismil oli progressiivne sisu: see tähendab objektiivse reaalsuse ja selle seaduspärasuste tunnustamist, veendumust inimese mõistuse jōus. Valgustajate deismi sotsiaalseks funktsiooniks oli võitlus feodaal-klerikaalse reaktsiooni ideoloogia vastu. Just niisugune oli Kreutzwaldi deism. Ta oli igasuguse dogmatismi vastu ja nimetas "kristlikku ebausku” "vaimseks rumaldamisvahendiks”, mis tōkestab progressi inimühiskonnas. ${ }^{29}$ Kodanlikud „kirjandusteadlased” püüdsid kramplikult kõnelda Kreutzwaldi loomuse ,sügavast”, ,transtsendentsest” jne. ,usundlikkusest”. Tegelikult samastas Kreutzwald, nagu ta seda otseselt väljendab paljudes oma kirjades, religiooni môiste hum a n $\mathrm{s}$ us i deega, ja see oli vaid üheks vormiks, milles avaldus tema sügav humanism, milles avaldusid tema ideed inimeste ja rahvaste vördsusest ning vendlusest.

Tunnetusteoorias asus Kreutzwald empirismi positsioonidel. Tunnetuse allikat nägi ta öigesti kogemuses, kirjutades: „Inimese vaim on sündimisel kui üks tühi tahvli-laud, kuhu peale hiljemini kõik sugusi asju võib kirjutada". ${ }^{30}$ See oli materialistlik empirism. Tunnustades objektiivse reaalsuse olemasolu, oli Kreutzwald ühtlasi veendunud selle tunnetamise võimalikkuses. Kreutzwaldi usk inimmõistuse tunnetavasse vôimesse ja suuresse jõusse oli aluseks ta väsimatule rahvavalgustuslikule tegevusele.

Kreutzwaldi ühiskondlik-poliitiliste vaadete sisuks oli vaen feodaalkorra ja selle igandite vastu ühiskonna elu kõigil aladel, kindel seisukohavōtt talurahva poolel.

Juba Kreutzwaldi varases publitsistlikus tegevuses, _ - ta artiklites ja sōnumites 1830. aastate lōpul ja 40. algul ajakirjas ,Inland" avaldub ta sügav kaastunne rõhutud, tema sõnade järgi ,haletsusväärsele ja ônnetule" 31 eesti talurahvale. Juba siin esineb Kreutzwald eesti talurahva huvide kaitsjana. Asudes kapitalismi arenemise demokraatliku tee positsioonil, oli Kreutzwaldi nagu Faehlmannigi taotluseks kōigi pärisorjuse igandite likvideerimine pōllumajanduses, eesti talurahva igakülgne prog-

26. Kreutzwaldi kiri J. Kölerile 19. oktoobrist 1864.

27 Kreutzwaldi kiri T. Beisele 29. jaanuarist 1860.

28 Kreutzwaldi kiri G. Sachssendahlile 12. septembrist 1854.

29 Kreutzwaldi kiri G. Sehultz-Bertramile 12. aprillist 1864.

so .Sipelgas". Tartu, 1861, 1k. 13.

a) Kreutzwaldi kiri Faehlmannile 1. oktoobrist 1845. 
ress ja hüvang, eesti talurahva kindel maaomand. Pōllumajanduslikke teadmisi ja ratsionaalset põllupidamist propageeris Kreutzwald eriti rahva hulgas laialt levinud „Kasulise kalendri” kaudu.

Kreutzwald käsitles eesti talurahvast ja balti mõisnikke kui vastandlikke ühiskondlikke jōude. Ta nägi balti-saksa paruneis ja pastoreis eesti rahva orjastajaid ja rõhujaid, kes eestlastes iialgi ei hakka năgema „,kasvôi ainult mingit liiki inimest", ${ }^{32}$ vaid suhtuvad neisse ainult kui veoloomadesse ja lüpsilehmadesse. „....Eestlased," kirjutas Kreutzwald, „pidid aastasadu jagama neegriorjade saatust, misjuures nende rōhujad tegid kōik selleks, et orjastatuid hoida loomataolises olekus ja kui nende tahe oleks täiesti teostunud, oleksid eestlased langenud ka lojusest madalamale." ${ }^{33}$

Kreutzwald nägi talurahvas aktiivset ühiskondlikku jōudu. Kui balti-saksa aadli ideoloogid, alavääristades eesti rahvast, väitsid, et see ei omavat mingit „rahvuslikku elujõudu”, ${ }^{34}$ siis meenutas Kreutzwald neile eesti talurahva korduvaid ülestōuse ajaloo vältel. ${ }^{35}$ „Seitsmesaja-aastases orjapõlves,” ütles ta, „vedas rahvas piitsahoopide all oma isandate koormat ainult näiliselt rahulikult, salvates oma sisemise viha suuraudadesse." 36

Kreutzwaldile oli iseloomulik terav vaen „balti erikorra” vastu, taotlus lähendada Baltimaid Venemaale. Ta nägi balti parunite privileegides „igasuguse edu kammitsaid". ${ }^{37}$ Juba 1840 . aastal nôudis Kreutzwald talurahva esindajate osavôttu haldusest ja kohtust, olles igasuguse "seisuslikkuse" vastu. $^{38}$ 1860. aastatel arendas Kreutzwald nōudeid, mis olid tüüpilised eesti rahvusliku liikumise demokraatlikule suunale - ta nõudis ülevenemaalise kodanliku kohtusüsteemi laiendamist Baltimaadele ja kōikseisuslikku maaomavalitsust. Selleks ajaks oli Kreutzwald veendunud, et kogu aadel ja samuti „balti erikord" on määratud paratamatule hukkumisele, hävides seda kiiremini, mida enam ta püüab ,,auke oma müürides kinni toppida keskaja murenenud kividega". ${ }^{39}$

Kreutzwald oli siiralt veendunud, et feodalismi igandite likvideerimine toob kaasa üldise heaolu. Ta kuulub nende valgustajate hulka, kes uskusid, nagu ütleb Lenin, ,.... täiesti siiralt üldisesse heaolusse ja soovisid seda siiralt, ei näinud siiralt (osalt ei vôinudki veel näha) vastuolusid selles korras, mis arenes välja feodaalkorrast", ${ }^{40}$

Kreutzwaldi mōtteviisi üheks kõige tüüpilisemaks jooneks oli ta avar humanism. Selle nimel oli ta igasuguse rōhumise, sotsiaalse ebavõrdsuse, rikkuse, ahnuse ja klassiühiskonnas vōimutseva kurjuse ning pettuse kirglik vihkaja, paljastades neid pahesid teravalt oma satiirilistes teostes. ${ }^{41}$ $\mathrm{Ta}$ arendas mõningaid utopistlikke mōtteid sotsiaalse ebavōrdsuse likvideerimisest. Seetôttu lähenes ta mõnel määral ka kapitalistlikule ühiskonnale omaste vastuolude mõistmisele. Kreutzwaldi „Eesti rahva ennemuistsetes juttudes” kajastub teravalt sulaste ekspluateerimine peremeeste poolt. Nähes 1860. aastatel jõukuse tõusu ühe osa eesti talurahva hulgas, nägi ta teiselt poolt talurahva suurema osa vaesumist. Nii kirjutab ta näiteks 1860. aastatel: ,Meie jōukad talupojad on suurimad egoistid ja tavaliselt imevad välja oma vaeseid naabreid igal vöimalikul viisil, andes neile tera-

32 Kreutzwaldi kiri A. Schiefnerile 1. maist 1859.

33 Kreutzwaldi kiri Yrjö Koskinenile 23, augustist (4. septembrist) 1866.

34 Inland, nr. 22, 28. mai 1822.

35 Revalsche Zeitung, nr. 143, (Extrablatt), 23. juuni 1862.

36 Kreutzwaldi kiri G. Schult2-Bertramile 5. novembrist 1869.

37 Kreutzwaldi kiri A. Schiefnerile 10. märtsist 1861 .

33 Kreutzwaldi kiri Faehlmannile 1. oktoobrist 1845.

s9 Kreutzwaldi kiri G. Schultz-Bertramile 13. mărtsist 1870.

40 V. I. Len in, Teosed, 2. kd., lk. 453.

41 Näiteks „Reinuvader Rebane”, Maarahva Kasuline Kalender, 1848-1851; eri raamatuna 1850,1860 ja 1869. 
vilja ja muid laene, nôudes neid aga tagasi kôige häbitumate liiakasuprotsentidega..." ${ }_{42}$ Kreutzwald kritiseeris ka Venemaa talurahvareformi, olles seisukohal, et see tähendab talurahva ruineerimist. ${ }^{43}$

Baltimaade valgustajad sageli ei näinud siinse olukorra iseärasuste tôttu oma otseste vaenlaste - balti parunite - selja taga kõigi Venemaa rahvaste ühist vaenlast - tsarismi. Rohkem kui keegi teine eesti hilisematest valgustajatest lähenes aga just Kreutzwald tsarismi reaktsioonilise osa mōistmisele. Oma avalikes, tsensuurist läbi käinud kirjutistes maksis Kreutzwald paratamatult tribuuti ,,armulisele keisri-herrale". Kuid tema kirjade pōhjal on ilmne, et ta teatud määral lähenes balti parunite ja tsarismi klassiliidu mōistmisele, ${ }^{44}$ et ta õigustatult kartis tsarismi ja vene ühiskonna reaktsiooniliste klasside venestamistaotlusi teiste rahvaste suhtes.

Uhiskonna arengu pōhitegurit käsitles Kreutzwald tüüpilise valgustajana idealistlikult, nähes ühiskonna arenemise alust eelkõige rahva vaimses kasvus. Kuid suure progressiivse tähendusega oli siiski see, et Kreutzwald oli sügavasti veendunud inimmõistuse loovates võimetes, mõistis eesrindlike ideede suurt ümberkujundavat jõudu ja võitles väsimatult feodaal-klerikaalse ideoloogia vastu. Suure kirglikkuse ja sarkasmiga paljastas Kreutzwald kõigis oma kirjades ja kirjutistes balti-saksa kirikuõpetajaid, nähes neis progressi ja vaimuvabaduse verivaenlasi. Nähes täiesti ôigesti aadli ja pastorite tihedat liitu, suhtus Kreutzwald pastoritesse kui rahva pimestajatesse ja otsestesse kurnajatesse, kui „mustas lambanahas huntidesse." 45 Oigesti määras ta ,hingekarjaste" sotsiaalse funktsiooni: „Külmetab kari talvel ja lõgistab hambaid, siis juhatatakse teda sealse paradiisi juurde ja ollakse ise rahul maapealsega." 46 Samuti paljastas Kreutzwald eesti rahvusest pastorite reaktsioonilise osa, näidates, et need on täpselt samuti rahva pimestamise ülesande teenistuses. ,Meie kirikuõpetajate hulgas on ka üksikuid eestlasi," kirjutas Kreutzwald 1866. aastal, , aga nad käituvad kui kōige puhtakoelisemad k i riku s a k$\mathrm{s}$ a d, nad on matnud oma ametikuue voltidesse kogu kaasatundmise rahvale ja selle huvidele." 47

Kreutzwald pühendas kogu oma jõu eesti rahva valgustamisele. Ta andis välja terve rea populaarteaduslikke teoseid ja kaua aastaid (1848-1873) rahva hulgas väga laialt levinud kalendrit, milles ta populariseeris pôllumajanduslikke $\mathrm{jt}$. teadmisi ja avaldas tähelepandava kirjandusliku väärtusega realistlikke, valgustavaid jutustusi. Oma populaarteaduslike teostega aitas Kreutzwald kaasa materialistliku maailmavaate juurutamisele rahvahulkades. Kui balti parunid veel 1860 . aastatel pidasid isegi kirjutamise ōpetamist eesti talurahva lastele tarbetuks vōi ohtlikuks, siis vőitles Kreutzwald juba üldhariduslike ainete, eriti loodusteaduste ōpetamise eest eesti rahvakoolis vaimunüristava usuōpetuse tuupimise asemel.

Samuti nagu Faehlmann oli ka Kreutzwald tōeline patrioot, kes armastas palavalt oma maad ja rahvast. Kuid ta oli ühtlasi internatsionalist, kes pōlgas igasugust rassismi. Ta pooldas kõigi rahvaste võrdõiguslikkust, olgu - nagu ta kirjutab - ,nende nahavärv kollane, must, tõmmu, valge ehk vasekarva". ${ }^{48}$

Kreutzwald mõistis õigesti eesti ja vene rahva ajaloolise saatuse seost,

42 Kreutzwaldi kiri J. Hurdale 6. maist 1863.

43 Kreutzwaldi kiri G. Schultz-Bertramile 31. märtsist 1870.

4t Kreutzwaldi kiri G. Schultz-Bertramile 21. oktoobrist. 1869

45 Kreutzwaldi kiri J. Kölerile 12. jaanuarist 1865.

46 Kreutzwaldi kiri J. Kölerile 12. aprillist 1866.

47 Kreutzwaldi kiri Yriö Koskinenile 23. augustist (4. septembrist) 1866.

48 F. R. Kreutzwa Id, Rahunurme lilled, Tartu, 1871, lk. 5. 
käsitledes seda paljudes oma teostes. Ta oli üks esimesi, kes rahvale määratud ilukirjanduslikes ja populaarteaduslikes töödes (poeemis „Sōda”, kalendrites jm.) näitas seda progressiivset tähendust, mida omas Eesti ala liitmine vene riigiga. Kartes oigustatult tsarismi venestuslikke taotlusi, mõistis Kreutzwald samas, et vene rahva toetus on hädavajalikuks eelduseks võitluses parema tuleviku eest. Ta kirjutas C. R. Jakobsonile: „Mida enam nüüd, mis Teie niisama hästi teate kui mina, meie tõsine armastus Venemaa poole avaldatud saab, seda vähem võivad postisarved ja nende puhujad (mōeldes sellega eesti reaktsioonileeri, kulakluse ideolooge ja parunite agente eesotsas Jannseni ja tema "Postimehega” - E. J.) meile kahju teha." 49 Kreutzwald võitles vene keele oppetamise eest eesti rahvakoolides.

Kreutzwaldi ühiskondlik-poliitilistes vaadetes esineb - ja see ei saa teisiti ollagi - rida vastuolusid ja kōikumisi. Tema juures võis vahetevahel esineda mōtteavaldusi, mis olid vastandlikud ta põhihoiakule - ta võis vahetevahel polemiseerides või kellegi peale pahane olles avaldada mōtteid, mis lähenesid kultuurtreegerlusele või kaldusid kokkuleplusse. Kuid niisugused kõikumised ei ole Kreutzwaldi maailmavaatele tüüpilised.

Eesti valgustajad, nende hulgas Kreutzwald, olles küll demokraadid, ei jõudnud revolutsioonilise demokratismini nagu vene talurahva ideoloogid XIX sajandi esimesel poolel ja keskpaiku. Kuid Kreutzwaldi looming ja tegevus, peegeldades eesti talurahva, ühiskonna rōhuva enamuse huve, oli suunatud eesti talurahva äratamisele ja valgustamisele ning tõepoolest aktiviseeris rahvast.

Paljud kõikumised ja vastuolud ületab. Kreutzwald oma rahvaluule alusel loodud ilukirjanduslikes teostes. Kreutzwald seadis endale eesmärgiks tõelise eesti rahvakirjanduse loomise või, nagu ta ise ütles, rahvale ta pärandi tagasiandmise. Selle suure ülesande Kreutzwald teostaski. Kreutzwaldi nagu kõigi tõeliste kirjanike looming peegeldab kōige vahetumalt, kõige otsesemalt rahva huve ja taotlusi. Kreutzwaldi loomingu kōrgeimaks saavutuseks on eesti rahvaeepos „Kalevipoeg” (ilmus esmakordselt 1857-1861, rahvaväljaandena 1862) ja kogumik ,Eesti rahva ennemuistsed jutud" (1865). Nende, eesti rahva võitlust röövvallutajate ja kurnajate vastu kajastavate teoste tähtsust eesti rahva vabastusvõitluse ja kultuuri ajaloos on raske üle hinnata. Neid võib nimetada eesti demokraatliku sisuga rahvusliku kultuuri vundamendiks. Nad mitte üksnes ei mobiliseerinud eesti talurahvast võitluseks balti-saksa mõisnike vastu, vaid olid innustajaks ka eesti töölistele võitluses tsaristliku isevalitsuse ning „oma” ja võ̃oramaiste kapitalistide ikke vastu, võitluses nõukogude võimu eest.

1860. aastad olid Venemaal eesrindliku ühiskondliku mõtte edasise tõusu aastateks. Oli seaduspärane, et suure ühiskondliku murranguga uute tootmissuhete rajamisega - kaasnes ka seda ülesannet teenindava eesrindliku ideoloogia tormiline tõus.

Venemaal tõusid talurahvahulkade revolutsioonilise liikumise juhtide ia ideoloogidena esile suured revolutsioonilised demokraadid N. G. TšernõŠevski (1828-1889) ja N. A. Dobroljubov (1836-1861), võideldes pärisorjuse ja isevalitsuse vastu. Nende ideoloogia avaldas suurt mōju ka Eestis. Vene eesrindlik ühiskondlik mōte, näiteks Tšernōševski teosed, vene vaba trükisõna - Herzeni „Kolokol” - kajastas ka eesti talurahva olukorda, väljendades ka eesti talurahva huve ja võideldes eesti talurahva olukorra eest. Olulise tähtsusega on fakt, et Herzeni „Kolokol” omas korrespondente ka Eestis - Tallinnas ja Tartus. On iseloomulik, et ühis-

49 Kreutzwaldi kiri C. R. Jakobsonile 10. oktoobrist 1878. 
kondliku mōtte tōusuga Eestis 1860. aastatel süvenes ka selle seos vene eesrindliku mōttega.

Demokraatlikku, pärisorjusevastast ideoloogiat kandvaks ringkonnaks oli näiteks eesrindlike haritlaste ringkond Tallinnas 1860. aastate algul, kuhu kuulusid N. F. Russov, V. T. Blagoveštšenski jt. Meenutagem, et see rühmitus andis 1861. a. välja niisuguse teose nagu „Eestlane ja tema isand", mis rikkaliku faktilise materjali najal tõepäraselt kirjeldas eesti talurahva julma ekspluateerimist balti parunite poolt. 1860. aastate esimesel poolel kujunes Peterburisse kogunenud eesti haritlastest nn. „Peterburi patriootide" ring, mis vene progressiivse kultuuri mõju tingimustes arendas feodaalkorra-vastast ideoloogiat, olles tihedas seoses eesti talurahvaga. Selle ringi väljapaistvaimaks tegelaseks oli maalikunstnik J. Köler.

Seoses uue baasi kujunemisega ja eestlaste konsolideerumisega rahvuseks algas umbes samal ajal ka eesti rahvuslik liikumine, olles suunatud võimutsevate balti-saksa mõisnike - suurmaaomanike vastu, kes püüdsid pehkinud feodaalkorda kujutada mingi kõrgema „,saksa kultuuri” kehastusena. Koos kapitalismi arenemise ja talurahva teadlikkuse tõusuga ilmnes ühtlasi mõisnike püüe eestlasi saksastada. Seetōttu omandas vōitlus feodaalkorra igandite vastu paratamatult rahvusliku värvingu. Eesti rahvuslikus liikumises kujunes välja kaks suunda — demokraatlik suund, mis väljendas laiade talurahvahulkade taotlusi, ja konservatiivne-klerikaalne suund, mis, kajastades eesti hallparunite huve, otsis kokkulepet feodaalidega. Rahvus. liku liikumise demokraatliku suuna väljapaistvamateks esindajateks olid Peterburi patriootide ringis välja kujunenud valgustajad-demokraadid (J. Köler, C. R. Jakobson).

Kreutzwald oli nii Tallinna progressiivsete haritlastega kui ka „Peterburi patriootidega" tihedas Rontaktis. Balti parunid nägid kõigis neis eesti talurahva ,ülesässitajaid”. Kreutzwald oli rahvusliku liikumise demokraatliku suuna väljapaistvaimaidesindajaid, astudes alati teravalt välja konservatiivse-klerikaalse suuna ideoloogide — eeskätt Jannseni — kui rahva pimestajate vastu. Ta näitas, et Jannsen koos oma ajalehe ,Eesti Postimehega" on mōisnike otsene, äraostetud käsik. Kreutzwald oli 1870. aastate lõpul Jakobsoni demokraatliku ajalehe „Sakala” kaastööliseks, avaldades siin võitlevaid artikleid.

Eespooltoodu pōhjal on ilmne, et 1860. aastatega, uute tootmissuhete vōiduga, tuleb alustada uut perioodi eesti eesrindliku ühiskondliku mōtte ajaloos, kolmandat perioodi eesti marksismieelse mōtte arenemises. Kapitalistlikud suhted olid nüüd valitsevad suhted. Et aga kapitalismi kiiret arenemist pidurdasid veel väga rohked pärisorjuse igandid, siis oli ka sel perioodil oluline tähtsus pärisorjusevastasel võitlusel.

1880. aastatel ilmnesid eesti ühiskonnas täie teravusega uued, kapitalismile omased vastuolud. Juhtiv osa rahva vabastusliikumises Eestis nagu kogu Venemaalgi läks nüüd proletariaadile. Siitpeale väljendasid töölisklassi ideoloogid ka talurahva huve ja algas täiesti uus etapp eesti eesrindliku mōtte ajaloos - marksismi ideede võidukäigu etapp.

\section{Eesti NSV Teaduste Akadeemia} Ajaloo Instituut 